\title{
A Rapidly Changing Reality
}

The Nature of the World Order and Crisis through the Eyes of Leading Experts in International Relations

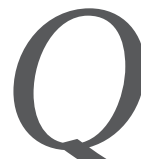

uantity has transformed into quality. Deformations and tensions in the world order, which have matured latently for years, if not decades, have come to light. The nature of changes in the modern world is yet to be comprehended. Not surprisingly, it is difficult to get rid of the Cold War inertial thinking and the temptation to find parallels in history. We have asked scholars and intellectuals from various countries to briefly assess the nature of these changes.

Pavel TSYGANKOV, Doctor of Philosophy, Professor at Comparative Political Science Department in the Faculty of Political Science at Moscow State University; Professor at World Politics Department, Moscow State Institute of International Relations

From a theoretical standpoint, the current situation in world politics can be described in terms of realism. Firstly, as a result of the collapse of the balance of power-the main condition for stability in international relations-after the end of the Cold War; secondly, as a result of the erosion of statehood and sovereignty, the major tenets of the world system; thirdly, as a result of imposing moralistic idealism.

The obviously tilted balance of power and the resulting imbalance of the United States have made that country feel invulnerable and 
prodded it into military ventures. The U.S. acts before the world the way Athens once did before Mytilene: "As for God's mercy, we have no reason to worry. We will not be defeated." The disappearance of the Soviet Union disrupted one of the laws of political equilibrium, according to which the U.S. and other major countries, in order to preserve the stability of the world system, either had to help Russia rise to the level of a great power or find a replacement for it in the same region. As we know, neither has happened. The alignment of Western allies around Washington as the sole center of globalization has only brought instability. The level of international security has been dramatically reduced by pressure on Russia and the defamation of its home and foreign policies, attempts to contain China, the plunging of the Middle East into chaos, the extraterritorial application of American law, the practice of regime change, including through "color revolutions," and support for radical opposition and terrorist groups. The escalating tensions carry the threat of a great war. Assurances by politicians and experts that there will be no war are not convincing because the deterrent role the nuclear factor played in the twentieth century has decreased significantly.

It would be incorrect to compare the current situation to the bipolar confrontation era because a second pole is nowhere in sight: Russia is weak, while China still hopes to "sit it out." One of the functions of this comparison is self-complacency: "Things went well then and will do so now, and tensions will give way to détente." In fact, the situation in the past was dangerous, too. As Raymond Aron wrote, "peace is impossible, war is unlikely." Tensions are only increasing today. International relations in the twenty-first century are not predetermined either, while differences are much more multidimensional than before. The risk of a global conflict is growing, although it is not fatal.

Globalization, sponsored by the U.S. and Western European countries, was conceived and promoted as a way to overcome the Westphalian system and give priority to supranational and transnational organizations over state sovereignty. U.S. sovereignty was not open to discussion, while Western European countries willingly delegated 
more and more of their statehood not only to EU organizations, but also to Washington. Like the U.S., they did not value the sovereignty of others, viewing it as an obstacle to globalization leading to universal prosperity. Therefore, European countries not only supported, but sometimes initiated the American practice of combating "sovereignism" through humanitarian interventions, the struggle against dictatorial regimes, the promotion of democracy, and "a responsibility to protect."

This practice has increased the number of conflicts, destabilized world politics, and boomeranged on European countries. It turns out that the U.S. and NATO are unable to protect Europe from uncontrolled flows of migrants and terrorist acts. The "threat of Russian aggression" no longer sells well and requires increasingly new hasty information campaigns, with their unifying role being doubtful. Economic difficulties, differences over anti-Russian sanctions, Brexit, Poland's opposition, the insubordination of Hungary and the Czech Republic, Italy's "rebellion," and Greece's discontent have destroyed the EU's image as a prosperous union. In turn, the Euro-Atlantic unity is undermined by Donald Trump's America First policy and emerging trade wars between the allies. Experts and politicians in Berlin, Paris, and Brussels today talk about the need to "take our destiny into our own hands," about protecting their economies, and even about a nation-centered policy and sovereignty. Yet their "turn to pragmatism" in the economy is still subordinate to political objectives; they will not stop interfering in the sovereignty of third countries (for example, Syria as a country with a "wrong regime"); and they keep repeating a mantra about commitment to common EuroAtlantic values.

The value and, in broader terms, moral conflict remains one of the main problems behind global tensions. The international relations theory has three interpretations of the relationship between politics and morality. One of them says that there is no place for morality in international politics as it is dominated by interests which are pursued at any cost. Another interpretation states that international politics must be subordinate to universal moral principles. The third one 
claims that morality in politics should be judged by the consequences of politicians' actions.

Of course, things are much more complicated in real life. One can see all the aforementioned three variants in the actions of any country. And yet it would be right to say that today we are witnessing divisions between major players along these three lines. China, which needs resources for its fast-growing economy, seeks to act moderately and cautiously, weighing its actions against possible consequences for trade. The U.S. proceeds from the presumption of cynicism in seeking financial profit, as Trump freely admits. The European Union has proclaimed the ideas of democracy, individual freedoms, and human rights as the main principles of its foreign policy and imposes them on everyone else, not caring much about how this may affect people of other cultures and Europe itself. Russia, which advocates traditional values in international relations, such as sovereignty, noninterference, and national security, is ready to go all the way to defend its independence. Concurrently, the narcissism of Euro-Atlantic countries and their pretensions to moral superiority over "undemocratic regimes" do not conceal their will to hold power and domination in international relations. The undisguised cynicism of the U.S. and the moralistic idealism of Europe destabilize the world system. American pretensions of "exceptionalism" and European pretensions of "universality" do not allow for dialogue with "others." In these conditions, normal diplomacy as an art of compromises is impossible, which is what we are witnessing today, although some changes are taking place in Europe, as was mentioned above.

Chas FREEMAN, Senior Fellow at Brown University's Watson Institute for International and Public Affairs; former U.S. Assistant Secretary of Defense; Ambassador to Saudi Arabia (during operations Desert Shield and Desert Storm)

World War II and the Cold War mixed geopolitics inextricably with ideology. For a half century, strategy and values seemed identical. They are again distinct. Operationally, geopolitics has now become a set of 
regional rather than global issues. The world has entered a time of unreason and indifference to institutions, principles, and precedents.

In the age of social media, celebrity is authority and the celebration of prejudice that is the "direct democracy" of assertive netizens sets the parameters for what is politically feasible. Ignorance and expertise have acquired equal weight in policy discourse. Convenient narratives and mass hallucinations displace strategic reasoning and analysis as the drivers of both policy and history.

Self-aggrandizing, solipsistic leaders fabricate populist identities, propagate their own delusions, act on them, and reject facts that do not fit their narratives. Self-righteousness preempts empathy-the prerequisite for both strategy and diplomacy. Bluster, bullying, boycotts, subversion, sabotage, and bombing supersede comity and negotiation as means for resolving disputes between nations.

A transition from a world order dominated by the United States and post-World War II institutions to a set of regional orders regulated by sub-global dynamics is underway. This transition would have been difficult under any circumstances. But the United States has complicated it by insisting on its global primacy even as it pulls down the lawbased international state system that it and the other Western victors of World War II created. The result is the unpredictable evolution of regional strategic challenges amidst a world order experiencing accelerated decay.

With the end of the Cold War, the United States incorporated most of the former Soviet sphere of influence into its own, pushing its selfproclaimed responsibility to administer world affairs right up to the borders of Russia and resisting the efforts of other great powers, like China, to share a role in governance of the regions they adjoin. The notion of a sphere of influence that is global except for a few no-go zones in Russia and China is now deeply ingrained in the American psyche. Moscow's and Beijing's unwillingness to accept this is a major factor in great power tensions in southeastern Europe, the Caucasus, and the Western Pacific.

The resulting impasse leaves unexamined the fundamental issues of regional strategic balance and competition that are the major 
sources of great power tensions at present. What are the appropriate roles of the United States, Russia, and the EU in the peaceful governance of Europe? Can intermediate states, like Ukraine, serve as both bridges and buffers between Russia and the EU? If so, how might this be arranged? What roles should China, India, Japan, the two Koreas, ASEAN, and the United States play in assuring peace and security in East and Southeast Asia? Can Iran, Israel, and the Gulf Arabs restore balances of power between them that constrain their rivalry to mutual advantage? And so forth.

The current strategic drift between great powers, left unattended, is more likely to produce catastrophe than peace and security. If legacy institutions are dysfunctional, the world will have to invent new ones at both the regional and global levels. Doing so would require a level and intensity of strategic dialogue between great powers that the world has not seen since the nineteenth century. And it would require adjustments in policy by the United States, China, Russia, and other great powers that none now sees the need to make.

\section{Raja MOHAN, Professor, Director of the Institute of South} Asian Studies, National University of Singapor; columnist on foreign affairs for The Indian Express, Delhi; non-resident Senior Associate of the Carnegie Endowment for International Peace, Washington DC

Any attempt to make sense of the current global disarray must come to terms with four important disruptions unfolding in the world. The first is the huge power shift between the East and the West. The common perception about the rise of China, and more broadly, Asia frame the problem as accommodating the new actors within the so-called "rules-based order" constructed by the West. That approach masks the real task-of recognizing and addressing the need for "systemic change" and not merely integrating the new actors into the global order. If nothing else the mere size of the Asian actors-China, India, and Indonesia-demands this. 
Second is the political backlash against globalization across the world, especially in the West that is questioning the traditional assumptions about open frontiers - to facilitate free movements of goods, services, and people. The losers-real and not so real-from the globalization are on the political warpath and posing profound challenges to the logic of globalism.

This problem is being aggravated by the third disruption-the massive new wave of technological innovation-centered around artificial intelligence, synthetic biology, big data, and new manufacturing technologies-that threaten traditional forms of economic organization that were developed during the era of the industrial revolutions in the 19th and 20th centuries. We understand even less about the impact of the new technologies on the distribution of global economic and political power. If the so-called fourth industrial revolution is at its infancy, the world's ruling elites are nowhere near imagining answers to the new questions being thrown up.

The three features feed into the fourth-the growing uncertainty in the domestic politics of leading powers. That the relative tranquility of domestic politics in the West may not be sustainable has been demonstrated by events like Brexit and the election of Donald Trump as the U.S. president at the end of 2016. Trump's unending foreign policy heresies may have shocked the American foreign policy elite but has not dented his domestic support. Meanwhile, large polities in the East are not immune to internal political change.

If the acceleration of all-pervasive change is the new feature of our time, students of international affairs will have to find ways of integrating the four disruptions into a reasonably coherent analytica framework.

\section{Dmitry TRENIN, Director of the Carnegie Moscow Center}

After a quarter of a century of unprecedented global domination by one power, the world order is in motion again. This motion is not only, and not so much, due to the rise of other major countries-China and India-or Russia's return to active politics. Even more important is 
the growing fatigue of the world leader, the U.S., caused by the burden of leadership, and Washington's desire to redistribute this burden. Trump's demarches in trade, his pressure on European allies to increase their share of the NATO budget, and the U.S. withdrawal from the Paris Climate Agreement are a harsher continuation of the policy started by Barack Obama to gradually reduce the United States' involvement in affairs beyond its borders.

In the 1940s, the U.S. began to build a Pax Americana and achieved much in this field. In particular, it entered the world war against Japan and Germany and, later, the Cold War against the Soviet Union, initiated the creation of the United Nations, built a system of international financial institutions, helped rebuild Western Europe politically, economically, and strategically, and created a worldwide network of alliances stretching from East Asia to Western Europe and from the Middle East to South America. In the words of President John F. Kennedy, the U.S. was ready to "bear any burden" in the name of the triumph of the cause of capitalist democracy. Now the era of liberal internationalism in Washington's politics is gradually coming to an end.

This process will take a long time. There will be no collapse, but a decisive turn has already taken place. U.S. policy will be increasingly influenced by national interests-naturally, as interpreted by those who will act on behalf of the United States-rather than by the interests of the "free world." The systemically important country, which insists on "fairness" in relations within the system it leads, thereby undermines the foundations of this system: any empire implies sacrifice and readiness to "bear any burden." Forsaking sacrifice is tantamount to forsaking empire.

Washington's attitude towards its allies is therefore more indicative than its attitude towards adversaries or rivals. The challenges that the U.S. now throws to friends are more significant than those thrown to adversaries. After 70 years of being under U.S. patronage, NATO countries, Japan, South Korea, Australia, and others have faced the objective need to prepare for independent foreign and military policies and take a new stand towards the United States. Of course, the U.S. will not leave this world, but will more firmly defend its interests from 
the position of the largest and most influential country, albeit less involved in world affairs. There will be no new Marshall Plans. America First! Yes. Pax Americana, RIP.

\section{LANXIN Xiang, Professor at Graduate Institute of International and Development Studies, Geneva; Director of Center of One Belt, One Road and Eurasian Security, China National Institute for SCO Studies, Shanghai}

The postwar "liberal international order" is imploding. It was created by the United States in 1945 and now the American administration is challenging almost every aspect of it, free trade, multilateralism, and the alliance system. It turns out that China and the rest of the world are still deeply embedded in this order.

What is the Chinese perspective on this new and disturbing phenomenon? Historically, there have been two "inevitability" theories. At one end of the spectrum is the theory of inevitability of China's integration into the liberal world order, which assumes that China will eventually be brought into this order through the process of globalization. Economically China will develop sufficient stakes in maintaining the liberal order from which it has benefited a great deal, but the end result is its democratization. At the other end stands the theory of inevitability of China posing destructive challenges to the existing international order.

China may not, however, go down either road suggested above. It has no fundamental reasons to destroy the current international order but would certainly be prepared to alter some rules of the game according to Chinese tradition, culture and national interest. Ironically, the chance of conflict with the West is higher when China's traditional outlook is fully "Westernized." Democracy never prevents expansionism of states (as the young American republic has testified). A Westernized China with an active territorial agenda would surely come into conflict with the United States just for geopolitical reasons.

The first debate about Chinese political legitimacy took place in the mid-17th century, known as the Chinese Rites Controversy (1645- 
1742), which was a bitter dispute within the Catholic Church over a fundamental question brought about by the Jesuit missionaries who admired the governance system in China. The gradual Western dominance of the wider world since the 18th century beyond Europe has created hegemony of Western thought, both explicit and hidden. The history of pre-modern Europe's rich interactions with China has been deliberately ignored by post-Enlightenment historians.

This orthodoxy obscured the relative position of the West itself during the tumultuous centuries of fighting for a respectable position as an "emerging power" on the global stage. During that era, its interactions with the non-West were characterized by competition rather than domination; accommodation rather than rejection, and negotiation rather than hegemony. Therefore, what China wants now is to return to the original cultural dialogue with the European Renaissance humanism, a dialogue that was brutally broken off by the Enlightenment in the 18th century. From a historical perspective, this is not an unreasonable demand.

\section{Alexander LOMANOV, Head Research Fellow at the Institute of Far Eastern Studies, Russian Academy of Sciences}

The West is losing its global leadership and now it will have to choose between resisting changes and adapting to them. Having lost the interest of, and the potential to attract, rising players, the West now wants to regain its "greatness." The problem is that these efforts are combined with attempts to slow down other countries.

The lack of confidence in its own ability to retain its leadership under the current rules of the game has caused the U.S. to trip up its partners. Trump's trade war against everyone is the first major battle. Western allies may take offense and respond with counter duties, but they are not ready for a military/political confrontation with the U.S. In contrast, China will have to fight to the end, using all its available resources. After long negotiations about reducing trade imbalances, the U.S. has strongly demanded that the Chinese government stop supporting new high-tech industries. For China, giving in to this de- 
mand would mean a suicidal abandonment of its "dream of revival" and global leadership.

Chinese analysts argue that Trump's actions are unreasonable and a result of the West's transition from the development phase to stagnation. The dangerous "Thucydides trap," about which Harvard political scientist Graham Ellison warned, is looming large. The conflict between a rising China and the aging hegemon, the U.S., has already made itself felt in the economy.

The U.S. pressure will force China to speed up its departure from strategic restraint in foreign policy, bequeathed by Deng Xiaoping. Every attempt to give a symmetric and painful response to the U.S. will provoke a spiral of confrontation in all areas. These developments look like George Kennan's prophecy fulfilled. Kennan warned about the danger of NATO expansion since it would provoke a predictably negative reaction from Russia. The West, which reveled in triumph after the end of the Cold War, took no heed of this warning, just as it ignored the warning about the "Thucydides trap," because confrontation with a rising China is an existential issue for the weakening West. The path of mutual concessions and adaptation is still open, but there are fewer and fewer chances to embark on it.

The inertia of the centuries-old Western-centric picture of the world reproduces an unreal opposition between a scientific and democratic West, and a dark and despotic East. In the foreseeable future, the West will not accept the growing East as an equal due to the feeling that it is "alien" and because of the West's latent racial and civilizational complexes.

In fact, the East does not yet have the tools to re-educate the West and teach it to appreciate other value systems and development models. Trump and the U.S. cannot be influenced by immature soft power. However, the successful use by China of market mechanisms in the economy, while maintaining a rigid political power vertical, looks increasingly attractive to countries that have not yet found a way to prosperity. This factor makes the reaction of the West, which does not want to become one of many, still stronger and more emotional. 
Gripped by populism and skepticism, the West is no longer an attractive goal for others. What will the world look like when the West no longer has advantages in wealth, military power, and innovations? Russia needs to think about this soberly and objectively. Russia's advantage is that it has not become part of the "collective West." This factor allows it to absorb new things without fear of conflict with regulatory institutional requirements and value attitudes. However, it will not be easy to realize this advantage. There will be a constant smoldering conflict among the elite between an unrequited love for the "European home" and the realization of real prospects for cooperation with the East. Russia's ineradicable belief that the West will come to its senses and understand that it cannot live without Russia may be a cruel joke. In a couple of decades, the long-awaited invitation to the "European home" may prove to be an invitation to the camp of laggards and losers.

It is not without purpose that the East wants so desperately to get rid of Western-centrism and create modern discursive systems that would reflect its value attitudes. China's intensive efforts to develop "social sciences with Chinese characteristics" have become a concrete embodiment of this trend. The refusal to comprehend its own reality using foreign criteria creates prerequisites for intellectual emancipation inside the country. Something similar is already happening and will continue to happen in Russia. The task of forcing oneself into the Procrustean bed of EU norms and standards is no longer relevant, given the sanctions, mutual alienation, and uncertainty about the future of the European Union itself. This factor expands the horizon for Russia's own innovations and searches.

The West's share in the world economy will continue to decline. Containing China will buy the West some time, but in this case the proportion will change due to the growth of other countries. In the long run, the West's hope that India will become its true ally may turn out to be as delusive as the previous policy of supporting China's development. New groups will emerge outside the "collective West" that will have a comparable potential. The real problem is not even that the Shanghai Cooperation Organization may suddenly become an eastern 
alternative to NATO in the distant future or that the Belt and Road Initiative will become a worthy replacement for the EU. The most dangerous thing will be a point of transition where the former world organizations will no longer be able to solve their tasks, while new ones will not yet have the tools and experience for that.

\section{Sir Robert Francis COOPER, a British diplomat, Former Special Advisor at the European Commission}

Dean Acheson's memoirs open with the words that the time he describes, "was one of great obscurity to those who lived through it. Not only was the future clouded, a common enough situation, but the present was equally clouded."

This was a time of disruption. It had been so since 1914; the climax came with the war of 1939-1945, and the chaos of the peace that followed. The people living then had an advantage: they knew that they did not know. We, blinded by the flashing lights of change, dazzled by its speed, overwhelmed by the stories we are told about the future, do not even know that we do not know.

It is seventy years since we had a direct military conflict between great powers. Is the great power war at an end, or coming to an end? Will there be a new form of great power, or of conflict? A conflict of mythologies perhaps? Nations, like religions, are based on beliefs which are not true. Who will decide such conflicts? They would need a referee.

What about the nations? They were made by the printing press. Once people could read the scriptures for themselves, they doubted them. Print turned local dialects into national languages, and made nations, helped national education and national industry.

Now devices appear that you wear in your ear, to interpret simultaneously. They do it badly now, but they learn quickly. Will national language still matter? Can technology that connects one day bring people together in identity and action? What will people die for? Once they died for survival, then for religion, then for nation: what next? For football? Or for nothing? 
There are no certainties. Except one maybe? We can imagine a future without religions, without states, without great powers; we cannot imagine it without iPhones or airplanes. That means that the one certainty is regulation.

The age we live in is always an age of obscurity. My guess is that we are moving into an age where the principle function of authority-and I can't imagine a world without authority-will be regulation.

There is only one certainty: THAT I AM WRONG.

\section{Francis A. KORNEGAY, Senior Research Fellow at the Institute of Global Dialogue, University of South Africa, Pretoria; an expert with Wilson Center, Washington}

The international system is undergoing a dangerously unstable transition. While not constituting a New Cold War, it reflects in part, the asymmetrical Cold War endgame, with what was already a shifting in the center of gravity of the global economy from West to East. In objective terms, global economic integration defines the world's interdependent and interconnected geopolitical economy. However, this eastward shift left in its wake a deindustrializing dynamic within the northern post-industrial economies of the West that, to varying degrees, has destabilized their postwar social and political compacts.

In the process, this has layed bare historical faultlines of socioracial, ethnic and cultural class contradictions that, given the emergence of information technology as weaponized instruments in geopolitical power-struggles, add a new and sinister dimension to the global transition underway. A nation's internal domestic divisions are exploited by external adversaries aiming to shift the targeted nation's domestic politics along a path of populist destabilization in the hope of shaping favorable geopolitical outcomes at the international level.

The racist targeting of African-Americans (among other groups) for voter suppression by Russian interference in the 2016 U.S. election aimed at contributing to white nationalist-populist alt-right "regime change" is emblematic of this dangerous new "hybrid warfare" trend in international politics. All the more so as this trend, in the service 
of reactionary anti-progressive conservative internationalism, in its cynical illiberalism, lends itself to obligatory "deniability." Denability is the essence of informational hybrid warfare which has its more "soft power" dimensions as well. In any case, the 2016 U.S. electoral outcome contributed to what amounts to an international right-wing conspiracy of strongmanism as a throw-back to the yesteryear of Great Power politics that gave us two world wars and the rise of fascism. Are we witnessing a form of international rigor mortis with the likes of $\mathrm{Pu}$ tin, Trump, Xi, Netanyahu, Erdogan, Salman, Modi, Dueterte among the more notable?

The question outstanding is whether or not the regionalizing of multipolarity in the emergence of regional economic communities will evolve towards a deepening of institutionalized global governance that reigns in Great Power geopolitical strongmanism in the eventual restabilizing of the international system, one where an amended liberal internationalism reflects a more democratically plural world order: Pluralist Internationalism with a reformed and strengthened United Nations at its core.

\section{Vitaly KURENNOY, Professor, Head of the School of Cultural Studies, National Research University-Higher School of Econom- ics, Moscow}

The contours of modern civilization continue to exist in the framework of modernity, while all those theories that hastened to announce the onset of a new, post-modern future have long become obsolete. In the field of international relations, theorists, too, hastened to declare the coming of a new era where the state, the main political unit of modernity, would finally lose its meaning, and nation states would be replaced by Empire. For quite some time the U.S. claimed this role, both as an international policeman and as the main authority supervising world networks and technological, financial, and other flows. What Napoleon had once tried to do in Europe by bringing civil freedoms and Code Civil to conquered nations, was now to be implemented on a world scale. 
But just like in the past, this scenario has not been realized. Whether Russia, Great Britain, or the U.S., countries are restoring their roles in various fields. The world of modernity is organized in such a way that makes the revival of a world empire impossible. Karl Rosenkranz, a right-wing Hegelian who, unlike leftists, better understood the reality in which he lived, wrote in the 1870 s that modern civilization was "oceanic." Rome took control of the Mediterranean Sea and therefore became a world empire within the then boundaries of the ecumene. But it is impossible to take control of the world ocean, Rosenkranz explained, because dreams of a world monarchy would inevitably be dashed by the free waves of the ocean, which rages on the shores of all parts of the world.

Does this mean that the holistic world of modernity has ended and we are now witnessing its final disintegration and inevitable political regionalization, fraught with frightening conflicts? This is possible as a relapse of relic political reflexes, but is impossible in a more fundamental sense, in what can be called a civilization of modernity that, according to Rosenkranz, is becoming more "uniform," standardized, or, if we use the term coined by George Ritzer, "McDonaldized." Unlike everything national, regional, or local, a global civilization is truly universal and rootless. The Roman sewage system, the British railroad, or the American Internet spread across the world and lost all connection with their places of origin. This is civilizational infrastructure in the broadest sense of the word; finance and law are also civilization. Civilization cannot be stopped because it has only one feature-it brings convenience and comfort to people. Civilization is chosen for the simple reason that it is more comfortable to have one's teeth treated under anesthesia than without it.

Civilization has costs, the most fundamental of which is the stress caused by the ever-increasing rate of change. Hence the craving for "stability," which political populists around the world have chosen as their slogan, although none of them can keep their promises simply because most people choose to have their teeth fixed with anesthesia. Civilization also means standardization. And while we are emotionally experiencing our sovereignization, civilization continues its relentless 
movement across the country, albeit slower than we would like. For example, it may take the form of compulsory star benchmarking and certification of Russian hotels (which is expected to be completed by 2021). At the same time, the world of modernity knows how to cope with its permanent stress and fears (for example, the widely-discussed fear that many professions will soon disappear). Some try to cope with this stress politically by taking a "special path," placing barriers to civilization and choosing a leader who would guarantee their very special way of life. However, the outcome of this special path is well known; therefore, let us think about a good option instead. This good option lies in the sphere of culture.

Hermann Lubbe contends that we compensate for the costs of the dynamics of modern civilization through historicization and museification of our local specifics. When civilization enters a territory, it causes a reaction from the local population, who try to preserve their identity or, if there is nothing left to preserve, invent their own culture, traditions ("traditional values"), or, better still, a national cuisine. What is the most strategically reasonable investment today? You can easily point out things that have an infinite payback horizon"infinite" meaning lasting until the end of humanity as we understand it. These are in no way technologies or start-ups. Sooner or later all of them become obsolete and give way to others-such is the inexorable nature of creative destruction, embodied by the world of modernity. The only absolutely reliable investment is investment in the past-in historical monuments and museums and in the preservation of local uniqueness, because the civilization of modernity stabilizes itself in the most diverse forms of museification and preservation of the past. As we know, an increasing number of people are traveling around the world with standardized hotels specifically to see this preserved culture. Countries that for some reason do not have such culture then start "restoring" or even buying it, spending huge sums of money. For example, the United Arab Emirates recently paid 400 million euros solely for the use of the Louvre brand name on its new museum.

But in order for culture to revive and flourish this way, it needs civilization. If we lag behind civilizationally, then we are not interested 
in our own culture; there will not be lines to museums, but to fast food restaurants. Creating conditions for civilized life is the main task of a sovereign state in the era of modernity.

\section{Christopher COKER, Professor at the Department of International Relations at the London School of Economics and Political Science}

There are signs that civilization is making something of a comeback, claims Krishnan Kumar. But it is no longer the preserve of Western academics debating among other things whether we will witness a coming clash of civilizations. The concept is now on the lips of mainstream politicians. Take Vladimir Putin's Russia. As sociologist Lev Gudkov writes, the great epic of the Soviet period, the Great Patriotic War (1941-1945) is now regarded by many Russians as "a victory not only over Germany, but also over the West." And that reading of history is important because the war is considered by many Russians to be the most important event in their history. Or take Xi Jinping's China which now insists that cultural distinctions will not give way to universal values. It has even begun to advance cogent reasons for ignoring what it claims to be "Western" international law in the South China Sea by reference to a "geo-cultural birthmark." Even in Narendra Modi's India politicians insist the country is essentially a Hindu civilization whose origins can be traced back to the early Vedas. And this despite the fact that archaeological evidence suggests that for the first 200 years the Vedas were composed of a nomadic people from Central Asia who introduced horses to the Indian subcontinent for the first time.

So, what is going on? China and Russia now claim to be civilizational states, distinctive from the nation-states that put together the rules-based order which still governs our lives. In both countries political leaders warn their citizens that their countries will disappear as independent cultural units if Western ideas are allowed to circulate unchallenged. That's why the Chinese Communist Party likes to claim that the reform program which opened the country to rampant capitalism after 1979 springs from "the soil of China." Even in the case of 
music, the defense of Chinese values now includes a crackdown on the Western religious music tradition-no more performances of Handel's Messiah or Verdi's Requiem which are considered to pose a real danger to cultural integrity in the form of cultural contamination. In Russia the Minister of Culture accuses Netflix — the global film-streaming company-of being part of an American plot to subvert Russian society. In an effort to upgrade its defenses against outside influences his ministry has now introduced licences banning the media from showing any films that are deemed to "defile the national culture."

It's clear that the appeal to civilization is intended to diminish the appeal of the Western idea. At present it is still difficult to assess how far the language and concepts of civilization have reshaped popular thinking, but the longer they are invoked and the deeper they lodge in the popular consciousness, the more likely that the next generation of politicians will come to find themselves imprisoned by them.

\section{Hanns W. MAULL, Doctor of Political Science, Professor, Merited Research Fellow at Science and Politics Foundation, Berlin}

If the liberal international order is still alive at all, its state of health is certainly critical, and no single person has done more to contribute to this state of affairs than the one who is supposed to be its principle custodian: the U.S. president. This may seem ironic, but it is much more than a coincidence: The fact that Donald Trump was elected president of the United States reflects the deep-seated problems of American democracy, and his efforts to take the wrecking ball to the institutional and normative foundations of both that democracy and the liberal international order shows how closely and organically the two orders are intertwined.

Undeniably, the way Donald Trump is operating his great wrecking ball from the White House has considerable entertainment value. Yet the spectacle easily distracts attention from the damage he is causing. Take the example of the Kim-Trump summit: quite irrespective of its results and even of whether in the end it would happen or not, the way this summit was contrived and managed in the eye of the pub- 
lic has caused considerable damage. While in the past, negotiations between Pyongyang and others included only one party, the North Korean leadership, which could never be trusted, now this applies to both sides. If you do not believe that either Pyongyang or Washington is ready to throw the towel and capitulate, if you do not, in other words, believe in fairytales, you will realize that the negotiations about North Korea's de-nuclearization are, at best, about kicking the problems down the road and scoring points at home in the process. To call Donald Trump's negotiating style "transactional" is a euphemism: it is erratic and therefore undermines both rules and trust, the two essential ingredients for workable diplomatic compromises. Irrespective of the hype generated by the summit and its eventual outcome, it has already caused significant damage to the regional security order in East Asia. Simply ask yourself this: How likely did you consider the proliferation of weapons of mass destruction in the region beyond the present number of countries six months ago, and how likely do you think it is now, after Trump has demonstrated how little he cares about America's allies and America's treaty obligations? The governments of America's allies in the region can certainly be forgiven if they now think harder than before about possible alternatives to U.S. security guarantees.

This example illustrates how easy it is to cultivate illusions about the decay of our present, still liberal, international order. Among the most widespread illusions are: this is a Western order, and its demise therefore is a good thing; it does not matter, anyway, so who cares? and what is happening is the decline of the West and the rise of the rest, so why worry? Historical justice is done.

Why are those three propositions illusionary? The liberal international order indeed was a Western project at the beginning, but it became universal long ago, both formally and substantively. Formally, its foundational documents and institutions were agreed and supported by all, not just by the West; many non-Westerners play important roles in shaping that order. Substantively, the liberal international order reflects the rise of the universal forces of science and technology. These also were European initially, but nobody would deny that they effec- 
tively have become universal forces long ago. While it is true that the liberal international order is, as we saw already, organically linked to Western models of democracy, and that the Western model now is in a deep crisis in many Western countries, that crisis is not one of democracy per se but of specific historical forms of democracy. The idea of democratic government is universal, just as the forces of science and technology; its strengths are its respect for individual human freedom and dignity and the rule of law and its capacity for correcting political errors through learning. It may be that this democratic model of governance will not survive in the evolutionary competition with other models, but that is much too early to say. The crisis of democracy in the West (which does not affect all Western democracies but only some, and certainly does not affect those countries equally) has also begun to create a backlash and mobilize corrective social forces.

The second illusion is that the decay of the liberal international order will affect only the West. The operative term for this illusion in the liberal international order is: liberal, rather than: order. It rests on a second, deeper illusion-the illusion that the implications of that decay are predictable and can be controlled. This seems naïve: given the levels and densities of what China today likes to call "connectivity" (or, if you prefer, interdependence) between individuals, societies and nation-states within this international order, the ramifications of decay will often spread far and wide in ways that are hard to foresee and even harder to channel, let alone control. Who will suffer the consequences of the decay of the liberal international order therefore is a wide-open question; its answers are bound to surprise, most likely surprise unpleasantly.

The third illusion ("Why worry?") is related: it assumes that the demise of the liberal international order is accompanied by the "Rise of the Rest," as Fareed Zakaria famously put it. Yet that assumes that the world is undergoing a major shift in the international distribution of power from one group of countries to another group. That is certainly true, but it is only part of a much broader transmutation of power, in which both the nature and the distribution of power in the international system are undergoing far-reaching changes. The bottom line of 
this is not the rise of the rest, but the rise of the many and the growth of asymmetries of power in international relations. From this perspective, power not so much shifts as it becomes dispersed: more and more actors individually are able to influence the course of history, but each of them less and less. This holds even for the most powerful entities we have seen in history, the great powers of today, such as the United States or China. With all its powers, neither the former Soviet Union nor the United States were able to pacify Afghanistan, and the regime in North Korea essentially has been able over the last two decades to dupe and manipulate all the other countries in the Six-Power-Talks quite successfully. So much for being powerful! The reason why the national power even of the greatest of today's nation-states remains limited is the exponential growth of complexity in today's world of globalization. One implication of that complexity is vulnerability; this makes it easy to mobilize power for destructive purposes. Yet it often has become fiendishly difficult to mobilize power for constructive purposes, as this requires that all the parties with some influence (through their destructive or veto power) need to be either coopted or neutralized. It therefore seems much more likely that the demise of the West and the decay of the liberal international order will result not in the rise of the rest but in the spread of disorder. Be careful what you wish for!

\section{Samir SARAN, President of Observer Research Foundation, New Delhi}

The world is not in disarray, it is in transition. As wealth and power move to the South and the East again after a couple of centuries, the validity of some normative assumptions and the efficacy of incumbent institutions that manage the world order is being severely tested. Over the past 70 years, globalization has generated enormous wealth for the Atlantic countries. In the last three decades however, Asia has managed to capture a majority share of global growth. As a result, the traditional Western guarantors of the post-World War II international order have seen their middle-classes squeezed by this 
development even as their elites devise means to cling to their pole position in world affairs.

This resurgence of the East, and its backlash in the West, manifest themselves in four trends.

First, diffusion of power-from the West to the East-is straining systems of norms and institutions that have defined the past seven decades. Powers like Russia and China see in this global rebalancing an opportunity to reduce American influence globally, and correct what they perceive to be inequitable rules. When they are (re)asserting their spheres of influences, they are seeking to redress the seemingly a-historic character of the extant world order.

Second, industrialized democracies are unable to respond to the challenges brought about by the rebalancing of economic power because of domestic compulsions. Coupled with technological disruptions and unfavorable demographics, the diminished share of the global economic pie feeds nationalism and populism in America and Europe. Significantly, political polarization inhibits their willingness and ability to consolidate and defend the international order created by them. The result is a slow-growing vacuum at the heart of global politics.

Third, (re)emerging powers are staking claim to leadership in this vacuum. China is the most prominent-though not only-country to be doing so. Economic integration, once anchored by the West, now finds a proponent in Beijing. However, unlike them, China sees little merit in conforming to the principle of free markets or to abide by the rules of the past. Instead, it seeks to advance an alternative model that is fundamentally rewiring the global institutional landscape through initiatives such as the BRI. Others, such as India, are forging their own paths to the global high-table by seeking pathways that are less disruptive.

Finally, Eurasia (along with much of its maritime periphery) as a geopolitical theater remains ill-defined and contested. Because no power is strong enough to impose its will upon all others-a corollary of diffused geopolitical power-a fierce multi-way tussle is underway where ad-hoc axes and convenient coalitions abound. The recentlyresurrected Quad, a bloated NATO, or the Russia-China-led SCO are 
manifestations of this geopolitical uncertainty. It is not too far-fetched to imagine that one or more of them, in some version, will eventually contribute to a "Great Power concert" model for 21st-century Eurasia, predicated by pragmatism and not ideology.

\section{Alexander FILIPPOV, Full Professor at the National Research Uni- versity-Higher School of Economics; Head of the HSE Center of Fundamental Social Science}

At the end of the last millennium, John Rawls, perhaps the most important political philosopher in the U.S., published his book The Law of Peoples. The title unambiguously refers both to the modern concept of international law and to the old European term "jus gentium." However, Rawls did not want to remain within the tradition. He proposed what he called a "realistic utopia." "I shall use the term 'Society of Peoples' to mean all those peoples who follow the ideals and principles of the Law of Peoples in their mutual relations," he wrote. All of them have rules of their own, be it a constitutional liberal democracy or an illiberal, but worthy government.

Let us dwell a bit on this utopia, whose reality Rawls did not overestimate. He clearly understood the possible and natural objections to it. The point is not that an influential author invented something in which he alone wanted to believe. On the contrary, his reasoning was obviously influenced by the spirit of the era. According to Rawls, world society should consist of peoples rather than states. Peoples, like every person, have a certain "moral character," so the principles of cooperation common to liberal peoples (and, partly, to worthy, albeit illiberal, peoples) can serve as the basis for organizing interaction among countries. In a sense, states have not changed since ancient times; they are ready to wage wars and impose their sovereign power on others, notwithstanding the latter's ideas of dignity and justice. Liberal peoples do not wage wars, except for the sake of self-defense, and do not fight each other. They seek agreement, including with illiberal peoples, against which no sanctions should be imposed and which should be allowed to develop the way they like. 
Perhaps there will come a time for the noble ideas of Rawls, and the majority of illiberal (in his terminology) people will become, if not liberal, then worthy, while liberal people will move even closer to their ideal. Thus, there will be no misunderstandings between them, which still happen now and then. Yet the spirit of the times has obviously changed over the past two decades. It seems very important to me to fix this vague, indefinable circumstance. The interests of states are stable, at least in the sense that they cannot be reduced to the interests or inclinations of the people who govern them. The geopolitical situation, the correlation of forces, and long-term tendencies are not something unexpected. But there is something that in certain circumstances makes possible trust, compliance, and readiness to look at one's own position from another point of view. Although at other times the situation changes completely and the issues of rightness, justice, and dignity come to a head and there is simply no one to solve them. We are witnessing the disappearance of the position of a privileged interpreter of events or, at least, a group of competing privileged interpreters.

Historically, it is known that such situations develop extraordinarily quickly and look like sudden quarrels between friends or good partners. They may lead to wars which, in turn, alternate with periods of more or less reliable peace, ensured not only by military superiority of the winners, but also by a leading, controlling position within the new consensus. Of course, this is not an exhaustive analysis of the problem: we are only repeating that everything or almost everything has gone wrong, that this is dangerous, that such things have already happened, and that this situation should not be reduced to a simple, one-dimensionally understood game of interests.

What else? Developments over the past thirty years-the time of the rise and fall of a great idea, and the great narrative of globalization-have been very instructive in some respects, above all in a spatial sense. By the way, the idea of globalization meant the disappearance of territoriality as the basic principle of the international system. Territories are states, while states are citizens and political processes are dependent on mutual support between citizens and states. Within 
the borders of states, there is the national economy, taxes are collected and distributed, and so on. Globalization means the emergence of an economy of networks and flows, a shift of the center of gravity to global centers that have complicated relations with states, the removal of numerous processes from state (civil and legal) control, and their transfer under the control of international bureaucratic organizations that are not responsible to anyone. The return of the state as the main agent of international relations and the political/ideological machine of citizens' solidarity, which we are now witnessing everywhere, means a not very effective, yet increasingly decisive, rejection of globalization costs. At the same time, it is also a rejection of the narrative and selfevidence of the supra-state community, so evident in the previous era. A new partition of the world along the borders of territorial states as the main political/spatial unit is still a long way off, but this prospect should not be underestimated.

There is no language to describe other, non-state territorial entities, except for some known unions. Equally important is the matter of time. The horizon of the future has suddenly closed. What is left are situations that need to be reacted to, long-term treaties, and the expectation that some problems will be solved only in a distant future, beyond the lifetime of those who make decisions now. There is no other future, no big goals, and no condition that needs to be achieved, such as the establishment of democracy or secular rule everywhere or victory over old epidemics. Instead of complex common goals, tasks of states' self-preservation have emerged, and resources and territories have grown. Without a new conversation about justice, the common good, and desirable transitions, one can expect nothing but egoism shown by each country.

\section{Bruno MACAES, State Secretary for European Affairs, Portugal, in 2013-2015}

After 1815 Europeans are said to have turned their eyes away from the starry sky of Revolution to the world as it was: Europe was at least an idea grounded in physical reality, one could do something 
with it and respond to its challenges and complexities. Something similar is now happening with the United States. Bruised and disillusioned with the idea of the West, American thinkers and decisionmakers are looking for something less ideal, something they can work with.

The West was an ideal point. One could approach it, but it would always recede the closer one seemed to the goal. For a century at least, American foreign policy has been based on a "double world" view. The world is divided into two halves, separated by a civilizational barrier, but one of the halves is continuously expanding and is meant-in the ripeness of time and perhaps after a great battle-to become universal. The United Stares saw itself as leading this process, leading the West in its expansive movement. Relations with the other half-the dark side of the earth-were always relations with a civilizational other, even when stable and peaceful.

What we have now is different. The expansive movement came to a sudden halt, disappeared. The two halves are combined and the barrier between them collapsed. American foreign policy now deals with Europe, Russia, China, India as parts of the same system-defending its interests in a system of relations where it strives to occupy the center. The critical difference is that the system is no longer dynamic, it is not in the process of approaching an ideal state.

Like Europeans after 1815, we need a word to refer to the world as it is rather than the world as it aspires to be and there is a word which promises to do that for us, what "Europe" did for Europeans after 1815. That word is "Eurasia," the geography where economic, political and cultural power is concentrated. It is a place of conflict and contradictions, divided between different cultures and offering the biggest prizes for competition and control. Curiously, just as Europe in the nineteenth century lived in a precarious relation of distance and proximity to a powerful island-kingdom on its shores, so does Eurasia exert its appeal and attraction over the United States, a powerful state just across the sea from Maine or Alaska. U.S. foreign policy now exists in relation and by reference to Eurasia, which in this sense at least has replaced the ideal concept of the West. One could say the United 
States is becoming the realist power in a world of many idealisms: EU values, Belt and Road, Hindutva, the Russian soul.

\section{Anatol LIEVEN, Professor at Georgetown University in Qatar; a member of the Valdai International Discussion Club}

The United States today illustrates something that has been apparent for a long time in the Middle East: the extreme difficulty of maintaining orderly government, let alone democracy, where very large parts of a country's population disagree radically about the fundamental ethnic or cultural identity of their state. U.S. foreign policy, in turn, is becoming not the result of considerations of U.S. national interest, but rather a function of America's growing domestic political hysteria, sharpened further by the stresses caused by the decline of U.S. global power. In addition, the growing economic insecurity of large parts of the white population is producing approaches to international trade which risk another global economic depression.

The picture is not completely dark, though. A political culture in which facts and evidence no longer matter and "debate" is a matter of spin, perception, cultural allegiance, and invention, is certainly a depressing picture for anyone who believes in human reason. On the other hand, such a culture has its advantages in foreign policy. If the entire U.S. official portrayal of North Korea and its leader can be turned on its head overnight while most of the Republican establishment and media nod in approval, then who knows what future transformations may be possible?

It is also important to note that the U.S. population is bellicose in its language, but not at all in its personal desire to fight. Crucially, this is also true of the Pentagon, both when it comes to further counter-insurgency campaigns and to war against other great powers. The U.S. made a great deal of noise about the Georgia-Russia war of 2008 and the Ukraine crisis of 2014, but there was never any serious chance of U.S. troops being sent to fight there. The U.S. might be compelled to fight if Russia attacked a NATO member-but the Russian government has no intention of doing so. Assuming that China does not push 
forward too recklessly in the South China Sea, the risk of great power conflict may therefore not be as great as some have feared.

The biggest short-term risk is a war with Iran; because Israel may attack in the hope of provoking an Iranian counterattack against the U.S., and a consequent U.S. destruction of Iran's economy. In the past, the Pentagon has acted to block such Israeli plans. It remains to be seen if it will be able to continue to do so under the Trump administration.

\section{Dr. Johan GALTUNG, Norwegian sociologist, mathematician, and thinker}

The 19th-20th century thought was dominated by the ideas of fundamental conflicts of private vs public, market vs plan. That clash of ideas defined the right from the left, but the conflict itself has dissolved altogether-with the political forces it bred. New discourses based on the basic needs of humans and nature-diversity, symbiosis-have not taken hold yet, but they may define a new left and a new right.

Whereas the West remained more or less the same during what we usually call the Cold War (1949-1989) and post-Cold War, the East has changed dramatically... The WTO was dissolved, while NATO indeed was not. However, now we got the Shanghai Cooperation Organization. The West tries to neglect it, but now it is not only Russia, China and a handful of Muslim countries but a prominent institution with India, Pakistan and very many of the 57 Muslim countries. Most of the world now does not follow that old simple pattern-the West vs the East, NATO vs the Warsaw Treaty Organization with the USA vs the USSR. That Cold War axis is losing dramatically in influence. We have a multipolar world now with only two states still belligerent, the United States and Israel.

Also, there is terrorism, state terrorism in its wake. But so far most of this multi-polar world has benefited from passive but peaceful coexistence. And while all take care of their part in addressing the global problems as multi-regional, the U.S. still tries to monopolize the globe financially, with the others making baskets of other currencies. 
The United States and Russia are both too strong to lose and not strong enough to win. Much more likely it will come to peaceful coexistence. The West will have to get used to it as it got used to decolonization, but they will try to penetrate Russia with its strong capitalism. The United States, for all kinds of reasons (above all, because it is bancrupt) will have to retreat to North America, its home. As for Russia, I believe it will focus on developing its enormous land mass-the envy of the West-not on expansion. How to do it is another matter.

\section{HUANG Jing, Merited Professor at Beijing Linguistics and Culture University}

The rise of China has irrevocably changed the economic, geopolotical and strategic landscape of the world, with three-dimensional implications to the world order and stability.

The first fundamental challenge as well as an opportunity brought by China's rise is to the global ecological system. As we know, the firstwave industrialization, which started the process of modernization in human history, took place in Western Europe about 250 years ago, involving less than 40 million people. The second wave, led by the U.S., Russia (USSR), Germany, and Japan with a population of over 400 million people, started in the late 19th and early 20th centuries. And now the rise of China, together with the fast development of India and the Southeast Asian countries, marks the third wave of modernization, involving over 4 billion people!

However, the model of achieving modernization through industrialization, which means massive consumption of natural resources and rampant urbanization, is by no means sustainable. Should China and other Asian countries accomplish their modernizations with this industrialization-led model, the human being would be doomed. Thus, how to find an alternative path towards modernization while sustaining our vulnerable ecosystem is a mission the world community, especially China, cannot afford to fail. It is the realization of this stern reality that nations have come together and made a collective effort to meet the challenge to our ecosystem and optimize opportunity for the 
development of the world, resulting in the Tokyo Protocol in 1997 and the Paris Agreement in 2015.

Second, the rise of China is achieved through integrating into, rather than challenging, the existing international system. Rising within the existing international system has not only determined that China's rise has to be peaceful and compensating to the international community, but also enabled China to benefit tremendously from economic globalization, which was initiated and promoted by the U.S. and its allies in the 1990s after the disintegration of the USSR. Nowadays China has become the largest trading nation on earth, with an economy that is expected to surpass that of the U.S. in the next decade. Meanwhile, it also made China's further development dependent on global economic integration based on multilateral arrangements. The Belt and Road Initiative adopted under President Xi Jinping's leadership has showcased China's push to further economic globalization, which, in Beijing's point of view, will eventually lead to the formation of "the community of shared destiny" for human being.

Third, the rise of China, with fast expansion of its influence and impressive development of its military forces, has irrevocably changed the geopolitical and strategic balance among the major powers. As a result, a U.S.-dominated unilateral world is shifting towards a multilateral one, in which interactions among the great powers (the U.S., Russia, China, Japan, India, and the EU), rather than the U.S. hegemony, determine the outcomes of international affairs as well as the balance of power.

From the U.S. perspective, all of the above developments caused by China's rise have substantially undermined U.S. interests. Moreover, the U.S. political elites are convinced that it was the U.S. "engagement" policy towards China since the late 1970s-in an attempt to induce China into a "peaceful evolution" towards an Anglo-Saxonist democracy - that has enabled China to rise rapidly at the U.S. expense. The deep frustration that China would never "become like us," on the one hand, and the growing anxiety, even paranoia, that China is going to "take over," on the other hand, have led to a strategic consensus in the U.S. establishment, including both Democrats and Republicans 
despite some irreconcilable divisions between them, that China has emerged as a "strategic rival," hence the U.S. must take "strong and effective measures" to constrain, if not fully contain, the development of China. The aim is not only to roll back China's rise, but, more importantly, to make the U.S. stronger.

Thus, the Trump administration has adopted a tough approach against China. Economically, the U.S. has pledged to levy massive tariff taxes on imports from China, tightened the ban on high-tech exports to China, and put all investments from China under strict scrutiny. Moreover, the U.S. has beefed up its military presence in the region under the newly adopted "Indo-Pacific strategy," with an effort to form a quad-alliance among the U.S., Japan, India, and Australia against China. Given the increasing hostility towards China, some pundits claim that the two largest powers have entered a "new Cold War."

But it is not to be. A fundamental consequence of China's rise within the international system, with the encouragement by the U.S. "engagement" policy, is that the two countries have become irrevocably interdependent. This has made their relationship by far transcend the scope of bilateral relations. While all the issues between the two countries have global implications, virtually all the intractable global challenges (e.g., the Korean Nuclear issue) can hardly be managed, let alone solved, without communication, consultation and certain cooperation between the U.S. and China. Moreover, the U.S.-China relationship nowadays is actually defined by internal politics rather than whether Washington and Beijing can see eye to eye on a given policy issue. In both the U.S. and China, policymaking involves widely diversified interest groups with different stakes. For example, a policy hailed by Wall Street might upset human rights groups; environmental groups would oppose a policy supported by the energy industry; and manufacturers and farmers would be unhappy with levying high tariff taxes that could trigger a trade war between the two countries. Thus, although the U.S. has adopted a tough approach against China, endless struggle and bargaining among interest groups in the policymaking process has prevented the Trump administration from working out any comprehensive and cohesive policy framework so far. As a 
result, Trump's policies towards China are mostly ad hoc, and implementations are inconsistent or even self-contradictory.

Notably, similar situations also exist in China, although policymaking in Beijing is far less transparent than that in Washington. As a result, despite President Trump's "tough stance" against China, the stability of the bilateral relationship is essentially determined by the top leaders' strength and capability in reaching a compromise in internal politics. It is in this regard that Xi Jinping, who obviously holds a stronger authority in internal politics than Donald Trump, appears to hold the upper hand in the stormy situation between the two powers.

Strategically, interdependence amidst economic globalization has eroded the foundation for a "new Cold War", which would require four conditions. First, policymaking in both countries would have to be ideologically driven so that, second, the world can be politically divided into two camps against each other. Third, their economies would be independent of each other upon which, fourth, both sides could form alliances to sanction against each other.

However, like most countries today, policymaking in both the U.S. and China are essentially interest oriented, not ideologically determined. Hence it is virtually impossible that the world could retreat to Cold War dynamics, where nations are divided into two camps politically hostile and economically independent of each other. Moreover, although a U.S.-led security system has survived the end of the Cold War, the U.S. allies would be reluctant to join the fight should confrontation take place between the two superpowers. As for China, Xi Jinping made it clear in his speech at the Belt and Road Initiative summit in May 2017 that China would not pursue any alliance but would strive to foster partnerships with other countries.

Thus, despite Trump's high-profile measures against China, it is hard to imagine that either the U.S. or China would go to war against each other. This is not necessarily because they would give up the competition and even rivalry, but because it will be extremely difficult for both Beijing and Washington to achieve a policy consensus at home and form alliance abroad, which are necessary for a confrontation between the two global powers. 
However, the U.S. "tough approach" against China will have a farreaching negative impact on the world order and stability, not only because Trump's anti-China measures are an essential part of his "America first" unilateralism and anti-establishment impulse in international affairs, but also because China has already become a deeprooted stakeholder in all the three layers of today's international order, i.e., the political order centered on the United Nations and its affiliated organizations, the economic and trade order based on the WTO and other multilateral trade agreements, and the financial order maintained by the World Bank, the IMF, and other institutions like the ADB and AIIB. Thus, it is not surprising that even America's closest allies in Europe and Asia-despite their substantial differences with China in terms of value and political systems-are reluctant to join the U.S. in its effort to roll back the rise of China. This does not mean they support China at all. But like China, they are also deep-rooted stakeholders of the existing international orders that are based on multilateral arrangements. After all, the essential purpose of reckless unilateralist behavior by the Trump administration (e.g., withdrawals from the Paris Agreement, the Iranian Nuclear Deal, the UN Human Rights Council, levying heavy tariff taxes on almost all important trade partners, and urging allies to pay more for the U.S. security commitments) is to rewrite the rules of the game in international affairs on America's terms at the expense of the entire international order. It is in this regard that Trump's "America first" has turned into "America isolated" because such an approach hurts all the stakeholders of the existing international order, including the U.S. allies.

By contrast, China's response to the U.S. pressure sounds rational and positive. Xi Jinping made it clear in his speeches at the Boao Forum for Asia in April 2018 that China would resolutely continue its reform and openness policy. Meanwhile, Beijing will firmly defend the free trade system based on multilateral arrangements, on the one hand, and carry on its "peaceful development" strategy, on the other hand. While it remains to be seen whether, and to what extent, China can turn the rhetoric into credible actions, how, and by what means, China can manage the volatile relationship with the U.S. under a highly self- 
centered and unpredictable Trump administration will indeed have a far-reaching impact on peace and development of the world. The good news is that Trump's ego-driven and unilateral behavior can actually strengthen China's hand, only if Beijing can handle it appropriately. The bad news is that the U.S. still is the strongest power on earth.

\section{Oliver STUENKEL, Professor of International Relations, Getulio Vargas Foundation, São Paulo, Brazil}

Global order is in a flux, and multiple trends-above all the rise of China and the highly disruptive Trump presidency-are forcing analysts around the world to make sense of a rapidly changing international system. In this context, there is a temptation to draw historic parallels to previous moments in history-China, some argue, can be compared to Wilhelmine Germany, a dangerous rising power. Others say we are entering a new Cold War. Yet while such arguments are sometimes useful, in most cases they fail to capture a far more complex reality. Worse, they create a fatalistic understanding of history and tend to limit our capacity to think about the opportunities that contemporary dynamics offer. The Cold War paradigm is a classic example. Whereas countries around the world had to articulate their strategy in the context of a U.S.-Russian superpower competition, no such situation exists today. Countries such as Brazil do not have to compromise and maintain good ties to Russia and China (through the BRICS grouping) and the United States. Comparing China to an aggressive Germany prior to World War I is equally misleading: China is above all a status-quo power, the exact opposite of Germany at the turn of the century.

The future of the global order-no longer under Western rule-is generally seen as chaotic, disorienting, and dangerous, and many analysts say we are facing a situation akin to Europe in the 19th centuryseething with rivalry. Yet our Western-centric worldview thus leads us to underappreciate not only the role non-Western actors have played in the past and play in contemporary international politics, but also the constructive role they are likely to play in the future. With powers 
such as China providing ever more global public goods, a post-Western order will not necessarily be less stable than today's global order.

And while the transition to genuine multipolarity-not only economically but also militarily and regarding agenda-setting capacitywill be disconcerting to many, it offers new opportunities for more democratic cooperation than any previous order in global history, allowing greater levels of genuine dialogue, broader spread of knowledge, and more innovative and effective ways to address global challenges in the coming decades. Yet while history may offer many useful lessons in the process, the post-Western World order will, in many ways, be different than anything we have witnessed before.

\section{Charles A. KUPCHAN, Professor of International Affairs at Georgetown University; Senior Fellow at the Council on Foreign Relations}

Global affairs have entered an uncertain and volatile era. The driver of the turmoil is the simultaneous advance of two tectonic shifts. First, the onset of the digital age and globalization is causing profound socio-economic dislocation. Especially among Western democracies, while automation, foreign trade, and immigration are depressing employment and wages and threatening traditional sources of communal solidarity and identity. Angry electorates are supporting a sharp populist turn that is undermining deliberative democracy, pluralism, and a rules-based international order. Second, the global balance of power is undergoing an epochal shift. After roughly two centuries during which the West has enjoyed material preponderance, the Western democracies now account for less than 50 percent of global GDP. These two tectonic shifts are intimately related. The onset of the digital era is one of the main factors producing rapid change in the global balance of power.

Many observers foresaw the ongoing shift in the distribution of power; the rise of China, India, and other emerging powers has been long in the making. In contrast, the populist surge that has weakened the West, polarized electorates, and turned Western democracies against each other has caught most scholars and practitioners off 
guard. Indeed, political life inside the United States has become unrecognizable during the Trump presidency and Washington is deliberately seeking to undermine the international order it took the lead in creating after World War II. In the meantime, Britain is tied up in political knots as London navigates its exit from the European Union. The nineteenth century was the era of Pax Britannica and the twentieth was the era of Pax Americana. It speaks volumes that the two countries that played such a dominant role in shaping the last two centuries are now experiencing profound political dysfunction and engaging in self-destructive behavior.

Managing peacefully the ongoing shifts in the socio-economic order and global power would be difficult enough even if the West were cohesive and seeking to guide this dual transition. But heading into an era of social and geopolitical uncertainty, an absent Western anchor is particularly dangerous. The Kremlin may believe that it is in Russia's interest to actively promote divisions within Western electorates and foster tensions among Western democracies. But it will surely regret those steps if borders come back to life in Europe and the continent again falls prey to national and ethnic tensions, geopolitical rivalry, and even armed conflict.

It is too soon to tell whether this moment represents a historical inflection point or a temporary detour in the trajectory of the West and its ability to anchor an international system historically prone to war. But there are clear reasons to be anxious about our world and work hard to bring about a political rebound within the West. 